\title{
ANALISIS LAPORAN KEUANGAN SEBAGAI DASAR PENILAIAN KINERJA PADA PERUSAHAAN SEMEN YANG TERDAFTAR DI BURSA EFEK INDONESIA PERIODE 2015-2016
}

\author{
Melisa Patricia Novelina Pasiakan ${ }^{1}$, Stanly W. Alexander ${ }^{2}$, Sonny Pangerapan ${ }^{3}$ \\ ${ }^{1,2,3}$ Jurusan Akuntansi, Fakultas Ekonomi dan Bisnis, Universitas Sam Ratulangi, Jln. Kampus Bahu, Manado \\ 95115, Indonesia
}

E-mail : pasiakanmelisa@gmail.com

\begin{abstract}
Company's financial performance can be known from the aspect of financial ratios, such as Liquidity, Solvency, Profitability, and Activity ratios. The development of a company, can be seen and can be compared through the company's financial performance. This is certainly useful for investors, creditors, and owners to make profitable investment decisions. This study aims to assess the financial performance of PT. Semen Indonesia Tbk, PT. Indocement Tunggal PrakasaTbk, and PT HolcimIndonesia by using financial ratio analysis. This study uses secondary data from Indonesia Stock Exchange. The result of research shows there are differences of financial performance between PT. Semen Indonesia Tbk, PT. Indocement Tunggal PrakasaTbk, and PT Holcim Indonesia. Suggestions for the Management Party should further improve the performance of total asset management, so that efficient corporate finance will be better.
\end{abstract}

Keywords: Liquidity, Solvency, Profitability, Activity, and Financial Performance

\section{PENDAHULUAN}

Dalam era pembangunan yang semakin pesat, kondisi tersebut terlihat pada pertumbuhan ekonomi telah mengalami kemajuan yang sangat pesat, dilihat dari semakin banyaknya perusahaan yang tumbuh dan berkembang. Perusahaan didirikan dengan berbagai tujuan pokok, seperti memperoleh laba, meningkatkan harga saham, meningkatkan volume penjualan, dan mempertahankan kelangsungan hidupnya, untuk mencapai tujuan perusahaan tersebut, manajemen perlu memperhatikan dua faktor pokok, yaitu faktor eksternal dan faktor internal yang sepenuhnya berada dalam kendali perusahaan.

Setiap perusahaan memerlukan kinerja maka diperlukan laporan keuangan. Suatu laporan keuangan perlu dianalisis karena merupakan salah satu cara yang dapat digunakan perusahaan untuk menganalisis kondisi dan kesehatan keuangan perusahaan untuk mengembangkan perusahaan. Tujuan laporan keuangan adalah mempersiapkan informasi yang berhubungan posisi keuangan, kemampuan serta perubahan posisi keuangan suatu perusahaan yang bermanfaat bagi sejumlah besar pengguna dalam pengambilan keputusan ekonomi. Laporan keuangan disusun untuk tujuan ini diharapkan dapat memenuhi kebutuhan bersama sebagian besar pengguna. Suatu laporan keuangan bermanfaat bagi sejumlah besar pengguna apa bila informasi yang disajikan dalam laporan keuangan tersebut dapat dipahami, relevan, andal dan dapat dibandingkan.

Untuk dapat menginterpretasikan informasi akuntansi yang relevan dengan tujuan dan kepentingan pemakainya telah dikembangkan seperangkat teknik analisis berdasarkan pada laporan keuangan yang dipublikasikan. Salah satu teknik tersebut yang popular diaplikasikan dalam praktik bisnis adalah analisis rasio keuangan. Analisis rasio keuangan merupakan instrumen analisis prestasi perusahaan yang menjelaskan berbagai hubungan dan indikator keuangan yang ditujukan untuk menunjukkan perubahan dalam kondisi keuangan atau prestasi operasi di masa lalu dan membantu menggambarkan tren pola perubahan tersebut 
untuk kemudian menunjukkan risiko dan peluang yang melekat pada perusahaan yang bersangkutan. Berdasarkan hasil analisis tersebut selama beberapa periode tertentu dapat dilihat perkembangan kinerja keuangan perusahaan dari periode satu dengan periode yang lainnya, karena perhitungan rasio ini berdasarkan pada laporan keuangan yang dibuat oleh perusahaan. PT. Semen Indonesia (Persero) Tbk, PT. Indocement Tunggal Prakasa Tbk, PT. Holcim Indonesia Tbk merupakan perusahaan yang bergerak di bidang industri semen. Perusahaan ini dalam menjalankan aktivitasnya menggunakan dana yang cukup besar. Bentuk pertanggungjawaban atas pengelolaan dana yang cukup besar tersebut dinyatakan melalui laporan keuangan, untuk menilai kinerja dari lembaga diperlukan sekali analisis atas laporan keuangan tersebut. Rumusan masalah penelitian ini adalah bagaimana kinerja dari laporan keuangan pada Perusahaan Semen yang terdaftar di Bursa Efek Indonesia periode 2015-2016. Sedangkan tujuan penelitian ini adalah untuk menilai kinerja Perusahaan Semen yang terdaftar di Bursa Efek Indonesia periode 2015-2016 melalui sebuah proses analisis atas laporan keuangan dari lembaga tersebut.

\section{TINJAUAN PUSTAKA}

\section{Konsep Akuntansi}

Definisi Akuntansi. Menurut Haryono, S (2015) akuntansi sering disebut sebagai bahasa bisnis atau lebih tepat disebut bahasa pengambilan keputusan. Semakin dikuasai bahasa ini akan semakin baik pengelolaan berbagai aspek keuangan, selanjutnya menurut Sutrisno (2013) akuntansi adalah suatu proses mencatat, mengklasifikasikan, meringkas, mengolah, dan menyajikan data transaksi, serta kejadian yang bersambungan dengan keuangan akibat dapat dipakai oleh orang yang memakainya dengan mudah dimengerti untuk pengambilan suatu keputusan serta tujuan lainnya.

\section{Laporan keuangan}

Pengertian Laporan Keuangan. Menurut Budi Rahardjo (2016) "Laporan keuangan yaitu laporan berkewajiban manager antara lain atasan perusahaan atas menjalankan perusahaan yang dipercayakan kepadanya, kepada pihak-pihak yang berkepentingan (stakeholder) terhadap perusahaan, yaitu pemilik perusahaan (mengurus saham), pemerintah (badan pemerintah umum pajak), yang memberikan kredit (bank atau lembaga keuangan), maupun pihak yang berkepentingan lainnya.

Tujuan Laporan Keuangan. Menurut IAI (2015:5) "Tujuan umum dari laporan keuangan ini untuk kepentingan umum adalah penyajian informasi mengenai posisi keuangan (financial position), kinerja keuangan (financial performance), dan arus kas (cash flow), dari entitas yang sangat bermanfaat untuk menciptakan sebuah keputusan ekonomis bagi para penggunanya.

Jenis-jenis/Komponen Laporan Keuangan. Menurut Ikatan Akuntansi Indonesia, komponen laporan keuangan yang lengkap terdiri dari : Neraca, Laporan Laba Rugi, Laporan Perubahan Ekuitas, Laporan Arus Kas, dan Catatan atas Laporan Keuangan.

Pihak-pihak Pengguna Laporan Keuangan. Menurut Kerangka Dasar Penyusunan dan Penyajian Laporan Keuangan dalam Standar Akuntansi Keuangan (SAK) paragraph 9 (Revisi 2009), dinyatakan bahwa pengguna laporan keuangan meliputi investor sekarang dan investor potensial, karyawan, pemberi pinjaman, pemasok, dan kreditor usaha lainnya, pelanggan, pemerintah serta lembaga-lembaga lainnya dan masyarakat. Mereka memakai laporan keuangan agar memenuhi segala kebutuhan informasi yang berbeda. 
Konsep Analisis Laporan Keuangan

Pengertian Analisis Laporan Keuangan. Menurut Dwi Prastowo (2015:50) Analisis laporan keuangan merupakan suatu proses yang penuh pertimbangan dalam rangka membantu mengevaluasi posisi keuangan dan hasil operasi perusahaan pada masa sekarang dan masa lalu, dengan fokus utama dalam menetapkan estimasi dan prediksi yang paling mungkin mengenai kondisi dan kinerja perusahaan pada masa mendatang.

\section{Kinerja Keuangan}

Definisi Kinerja Keuangan. Menurut K. R. Subramanyam (2017:91) kinerja keuangan adalah pengakuan pendapatan dan pengaitan beban akan menghasilkan angka laba yang lebih unggul dibandingkan arus kas untuk mengevaluasi kinerja keuangan.

Tujuan Kinerja Keuangan. Menurut Munawir (2012:31) menjelaskan uraian maksud dari pengukuran prestasi keuangan perusahan adalah: (1) mengetahui tingkat likuiditas; (2) mengetahui tingkat solvabilitas; (3) mengetahui tingkat rentabilitas; dan (4) mengetahui tingkat stabilitas.

\section{Rasio Keuangan}

Pengertian rasio keuangan. Rasio keuangan menurut James C. Van Horne keadaan indeks yang menjadikan dua angka akuntansi dan diperoleh dengan membagi satu angka dengan angka lainnya. Rasio keuangan dipakai untuk menilai keadaan keuangan dan kinerja perusahaan. Dari pembagian rasio keuangan ini hendak memandang kondisi keadaan perusahaan yang bersangkutan.

Keunggulan Analisis Rasio Keuangan. Analisis rasio ini mempunyaii keutamaan dibandingkan teknik analisis lainnya. Keunggulan rasio keuangan menurut Sofyan Harahap (2013:298) adalah :

1. Rasio merupakan angka-angka atau ikhtisar statistik yang lebih mudah dibaca dan ditafsirkan.

2. Merupakan pengganti yang lebih sederhana dari informasi yang disajikan laporan keuangan yang sangat rinci dan rumit.

3. Mengetahui posisi perusahaan di tengah industri lain.

Keterbatasan Analisis Rasio Keuangan. Keterbatasan analisis rasio keuangan menurut Sofyan Harahap (2013:298) adalah kesulitan dalam memilih rasio yang tepat yang dapat digunakan untuk kepentingan pemakainya.

Pedoman Dalam Analisis Laporan Keuangan. Menurut S. Harahap (2013:313) dalam menafsirkan rasio laporan keuangan kita memerlukan alat pembanding agar rasio itu bermakna dan dapat kita nilai prestasi atau posisi perusahaan dan skala industrinya. Alat pembanding ini merupakan yardstik atau standar.

Penelitian Terdahulu. M Ashari AL Basahir Ak/2007 Analisis laporan keuangan untuk menilai kinerja keuangan PT British American Tabacco, Tbk Tujuan penelitian untuk menilai kinerja keuangan perusahaan PT British American Tabacco, Tbk metode penelitian yang digunakan Deskriptif Kuantitatif dari Rasio Likuiditas: Kinerja keuangan perusahaan yang digambarkan sudah menunjukan titik likuid tetapi bukan berarti mempertahankan saja melainkan perusahaan harus meningkatkan operasionalnya. Rasio aktivitas: penggunaan aktiva perusahaan sudah mendekati efektif akan tetapi lebih baiknya jika perusahaan tersebut memperhatikan dalam pengelolaan operasionalnya Rasio profitabilitas: Sebaiknya perusahaan tersebutlebih insentif dalam meningkatkan kestabilan operasionalnya. 


\section{METODE PENELITIAN}

Jenis Penelitian. Jenis penelitian yang digunakan penulis adalah penelitian deskriptif, yang dilakukan dengan cara mengumpulkan data yang berhubungan dengan permasalahan yang dihadapi.

Tempat dan Waktu Penelitian. Penelitian ini dilakukan pada Perusahaan Semen yang terdaftar di Bursa Efek Indonesia studi kasus pada PT. Semen Indonesia (Persero) Tbk, PT. Indocement Tunggal Prakasa Tbk, PT. Holcim Indonesia Tbk periode 2015-2016 dengan waktu penelitian bulan April 2018 - Juni 2018.

Prosedur Penelitian. Dalam penelitian ini analisis yang digunakan untuk menilai kinerja keuangan adalah menganalisis laporan keuangan dengan langkah-langkah sebagai berikut :

1. Mempelajari struktur organisasi Perusahaan Semen yang terdaftar di Bursa Efek Indonesia serta tugas dan tanggung jawab masing-masing dalam bagian struktur tersebut.

2. Mempelajari laporan keuangan tahun 2015-2016.

3. Menilai kinerja keuangan Perusahaan Semen yang terdaftar di Bursa Efek Indonesia dengan menggunakan rasio likuiditas, slvabiitas, profitabilitas dan aktivitas.

4. Menarik suatu kesimpulan dari hasil penelitian yang diperoleh.

\section{Metode Pengumpulan Data}

Jenis Data. Dalam melakukan penelitian ini berbagai jenis data yang digunakan yaitu data kuantitatif.

Sumber data. Data-data yang digunakan dalam melakukan penelitian ini adalah data sekunder.

Populasi dan Sampel. Populasi dan sampel dalam penelitian ini adalah laporan keuangan PT. Semen Indonesia (Persero) Tbk, laporan keuangan PT. Indocement Tunggal Prakasa (persero) Tbk, dan laporan keuangan PT. Holcim Indonesia (persero) Tbk yang diterbitkan selama dua tahun terakhir yaitu tahun 2015 dan 2016.

Metode Analisis Data. Metode analisis yang digunakan untuk membahas permasalahan dalam penelitian ini adalah metode analisis deskriptif.

Teknik Pengumpulan Data. Metode analisis laporan keuangan pada Perusahaan Semen yang terdaftar di Bursa Efek Indonesia yaitu :

1. Mengumpulkan dan menyajikan data berupa Laporan Keuangan selama 2 tahun (Tahun 2015 dan Tahun 2016).

2. Membandingkan Laporan Leuangan.

3. Menganalisis Laporan Keuangan dengan menggunakan analisis Likuiditas, Solvabilitas, Profitabilitas, dan Aktivitas, menginterpretasikan proses analisis sebagai perpaduan antara hasil perbandingan dengan kaidah teoritis yang berlaku.

4. Menentukan Kinerja Keuangan perusahaan berdasarkan hasil pengukuran/ analisis terhadap laporan keuangan perusahaan.

\section{HASIL PENELITIAN DAN PEMBAHASAN}

\subsection{Hasil Penelitian}

Gambaran Umum PT. Semen Indonesia (Persero) Tbk. PT. Semen Indonesia (Persero) diresmikan di Gresik pada tanggal 7Agustus 1957 oleh presiden RI pertama dengan kapasitas terpasang 250.000 ton semen pertahun. Pada tanggal 8 Juli 1991 Semen Gresik tercatesat di Bursa Efek Jakarta dan Bursa Efek Surabaya serta merupakan BUMN pertama yang go public dengan menjual 40 juta lembar saham kepada masyarakat. Sampai dengan tanggal 30 september 1999 komposisi kepemilikan saham berubah menjadi Pemerintahan RI 15,01\%, Masyarakat 23,46\% dan cemex 25,53\%. Pada tanggal 27 Juli 2006 keadaan telah berubah transaksi penjualan saham CEMEX S. S de. C. V pada Blue Valey Holdings PTE Ltd sehingga komposisi kepemilikan saham sampai saat ini berubah menjadi Pemerintah RI 
50,01\%, Blue Valey Holdings PTE Ltd 24,90\% dan masyarakat 24,09\%. detik ini daya tampung mengenakan Semen Gresik Group (SGG) sejumlah 16,92 juta ton semen per tahun, dan menguasai sekitar $46 \%$ pangsa pasar.

Gambaran Umum PT. Indocement Tunggal PrakasaTbk. PT Indocement Tunggal Prakarsa Tbk. ("Indocement") adalah salah satu produsen semen terbesar di Indonesia yang mengeluarkan berbagai macam jenis semenbermutu, termasuk produk semen khusus yang dipasarkan dengan merek "Tiga Roda". Indocement boleh mempunyai jumlah anak perusahaan yang memproduksi beton siap- pakai (Ready- Mix Concrete/RMC) serta mengelola tambang agregat Dan trass. Indocement dibangun tahun 1985, yang menjadi penggabungan dari enam perusahaan semen yang saat itu memiliki delapan pabrik. Pabrik utama Indocement resmi dilakukan sejak 4 Agustus 1975. Pada 5 desember 1975, untuk pertama kalinya Indocement mencatat sahamnya di Bursa Efek Indonesia dengan Kode transaksi INTP.

Gambaran Umum PT. Holcim Indonesia Tbk. PT. Holcim Indonesia, Tbk yaitu suatu perusahaan menjadikan semen di Indonesia yang sebelumnya bernama PT. Semen Cibinong, Tbk. menggantikan nama berjalan bersama dikuasainya berkelompok saham perseroan oleh Holcim Ltd, penukaran nama perusahaan dimulai pada 1 Januari 2006. Penukaran nama ini boleh diikuti oleh anak perusahaan perseroan PT Semen Cibinong Tbk yang berganti nama menjadi PT. Holcim Indonesia, Tbk. mulai tanggal 1 Januari 2005 dan juga PT. Trumix Beton menjadi PT. Holcim Beton.

\subsection{Pembahasan}

Tabel 1. Rekapitulasi Hasil Perhitungan Rata-rata Rasio Keuangan PT. Semen Indonesia Tbk, PT Indocement Tbk, PT Holcim Tbk

Tahun 2015-2016

\begin{tabular}{lrrrr}
\hline \multicolumn{1}{c}{ Rasio Keuangan } & $\begin{array}{c}\text { PT. Semen Indonesia } \\
\text { Tbk }\end{array}$ & $\begin{array}{c}\text { PT. Indocement } \\
\text { Tbk }\end{array}$ & $\begin{array}{r}\text { PT.Holcim } \\
\text { Tbk }\end{array}$ & $\begin{array}{r}\text { Rata-rata } \\
\text { Industri }\end{array}$ \\
\hline Rasio Likuiditas & & & & \\
Rasio Lancar & $143 \%$ & $470 \%$ & $55 \%$ & $222,66 \%$ \\
Rasio Cepat & $108 \%$ & $412 \%$ & $119,5 \%$ & $213,16 \%$ \\
Rasio Kas & $105,5 \%$ & $212,5 \%$ & $10,5 \%$ & $109,5 \%$ \\
Rasio Perputaran Kas & $15 \%$ & $28,5 \%$ & $24,6 \%$ & $23,7 \%$ \\
& & & & \\
Rasio Solvabilitas & & & & \\
Rasio Hutang Atas Modal & $41,5 \%$ & $15 \%$ & $125 \%$ & $60,5 \%$ \\
Rasio Hutang Atas Aktiva & $29 \%$ & $13 \%$ & $55 \%$ & $32,33 \%$ \\
& & & & \\
Rasio Profitabilitas & $17 \%$ & $24,75 \%$ & $2,4 \%$ & $14,71 \%$ \\
Margin Laba Bersih & $15 \%$ & $16 \%$ & $2,5 \%$ & $11,16 \%$ \\
Return On Investment/Equity & $10,5 \%$ & $13,5 \%$ & $1 \%$ & $25 \%$ \\
Return On Total Asset & $13 \%$ & $16,5 \%$ & $1,4 \%$ & $10,3 \%$ \\
Basic Earning Power & & & & \\
& & & & \\
Rasio Aktivitas & & & & \\
Rasio Perputaran Total Aktiva & $9,648 \mathrm{kali}$ & $0,576 \mathrm{kali}$ & $0,01 \mathrm{kali}$ & $0,411 \mathrm{kali}$ \\
Rasio Perputaran Piutang & $6,04 \mathrm{kali}$ & $6,57 \mathrm{kali}$ & $8,815 \mathrm{kali}$ & $8,14 \mathrm{kali}$ \\
Rasio Perputaran Persediaan & $10,79 \mathrm{kali}$ & $9,84 \mathrm{kali}$ & $16,80 \mathrm{kali}$ & $12,51 \mathrm{kali}$ \\
Rasio Perputaran Aktiva Tetap & $2,538 \mathrm{kali}$ & $1,205 \mathrm{kali}$ & $3,69 \mathrm{kali}$ & $2,47 \mathrm{kali}$ \\
\hline
\end{tabular}

Dari tabel tersebut di atas, terlihat bahwa kinerja keuangan PT. Indocement Tunggal Prakasa (persero) Tbk masih lebih baik dibandingkan dengan PT. Semen indonesia (persero) 
Tbk dan PT. Holcim Indonesia (persero) Tbk. Hal ini dikarenakan rata-rata nilai rasio keuangan baik di tinjau dari rasio likuiditas, profitabilitas, dan aktivitas, PT. Indocement Tunggal Prakasa (persero) Tbk di atas rata-rata industri hal ini mengidikasikan PT. Indocement Tunggal Prakasa (persero) Tbk lebih mampu dalam meningkatkan perputaran kekayaan maupun persediaanya untuk meningkatkan penjualan sehingga nilai profit yang dihasilkan oleh perusahaan tersebut juga lebih tinggi dibandingkan dengan PT. Semen indonesia (persero) Tbk dan PT. Holcim Indonesia (persero) Tbk. Demikian juga di lihat pada tingkat rasio solvabilitas perusahan baik di tinjau dari hutang atas modal dan hutang atas aktiva perusahaan. Tingkat rata-rata solvabilitas PT. Indocement Tunggal Prakasa (persero) Tbk lebih rendah dari rata-rata industri. Hal ini mencerminkan beban yang ditanggung dari PT. Indocement Tunggal Prakasa (persero) Tbk, dalam memenuhi kewajibannya jangka panjang lebih ringan di banding dengan PT. Semen indonesia (persero) Tbk dan PT. Holcim Indonesia (persero) Tbk yang memiliki nilai rata-rata solvabilitas di atas rata-rata industri.

\section{KESIMPULAN DAN SARAN}

\subsection{Kesimpulan}

Berdasarkan analisis dan pembahasan yang telah dilakukan terhadap neraca dan laporan laba rugi PT. Semen Indonesia (Persero) Tbk, PT. Indocement Tunggal Prakasa (Persero) Tbk, PT. Holcim Indonesia (Persero) Tbk periode 2015-2016 pada bab sebelumnya maka dapat disimpulkan sebagai berikut:

1. Dalam perhitungan analisis rasio likuiditas dengan menggunakan rasio lancar menunjukkan bahwa PT. Indocement Tunggal Prakasa Tbk memiliki kinerja keuangan yang lebih baik dibandingkan dengan PT. Semen Indonesia Tbk dan PT. Holcim Indonesia Tbk yang rasionya di bawah rata-rata industri. Sedangkan dengan menggunakan rasio cepat, rasio kas dan rasio perputaran kas menunjukkan bahwa PT. Indocement Tunggal Prakasa Tbk kinerja keuangannya lebih baik dimana perusahaan dapat memenuhi kewajibannya tanpa harus tergantung dari persediaannya sedangkan PT. Semen Indonesia Tbk dan PT. Holcim Indonesia Tbk yang rasionya di bawah rata-rata industri.

2. Dalam perhitungan rasio solvabilitas yang terdiri dari rasio hutang atas modal dan rasio hutang atas aktiva menunjukkan bahwa PT. Indocement Tunggal Prakasa Tbk keuangannya lebih baik dan diikuti oleh PT. Semen Indonesia Tbk dibandingkan dengan PT. Holcim Indonesia Tbk yang kinerja keuangannya kurang baik maka PT. Indocement Tunggal Prakasa Tbk dan PT. Semen Indonesia Tbk dengan semakin rendahnya rasio hutang menunjukkan semakin kecil resiko yang dihadapi perusahaan.

3. Dalam perhitungan rasio profitabilitas dengan menggunakan margin laba bersi, return on investment/equity, return on total asset dan basic earning power menunjukan bahwa PT. Indocement Tunggal Prakasa Tbk memiliki kinerja keuangan yang lebih baik di bandingkan dengan PT. Semen Indonesia Tbk dan PT. Holcim Indonesia Tbk yang kinerja keuangannya kurang baik. Hal ini menunjukkan bahwa PT. Indocement Tunggal Prakasa Tbk mampu mengelola modal yang diinvestasikan dalam keseluruhan aktiva maupun modal sendiri untuk menghasilkan laba bersih.

4. Pada rasio aktivitas yang diukur dengan rasio perputaran total aktiva, Rasio perputaran piutang, rasio perputaran persediaan dan rasio perputaran aktiva tetap menunjukan bahwa PT. Holcim Indonesia Tbk kinerja keuangannya lebih baik dibandingkan dengan PT. Semen Indonesia Tbk dan PT. Indocement Tunggal Prakasa Tbk. Hal ini menunjukkan bahwa PT. Holcim Indonesia Tbk sangat baik dalam mengelola aset atau aktiva maupun seluruh aktivanya sehingga mampu menghasilkan penjualan dan dapat meningkatkan perputaran aktivanya dari tahun ke tahun. 


\subsection{Saran}

Berdasarkan hasil penelitian dan kesimpulan yang telah ditemukan maka penulis dapat memberikan saran saran yang berkaitan dengan penelitian ini sebagai berikut:

1. Dilihat dari analisis rasio, menunjukan bahwa rasio keuangan PT. Semen Indonesia Tbk, PT. Indocement Tunggal Prakasa Tbk, PT. Holcim Indonesia Tbk periode 2015-2016 begitu baik namun masih ada rasio yang harus diperbaiki. Untuk itu perusahaan diharapkan untuk tetap mempertahankan rasio-rasio yang mengalami peningkatan. Sedangkan untuk rasio yang mengalami penurunan, perusahaan diharapkan memperhatikan faktor-faktor yang menyebabkan penurunan ini dan memperbaikinya.

2. Perusahaan harus meningkatkan kinerja terhadap pengelolaan total aktiva, sehingga efisien keuangan perusahaan akan menjadi lebih baik.

3. Untuk meningkatkan kinerja perusahaan agar lebih baik dari tahun ketahun perusahaan harus mampu mengelola keuangannya dan hendaknya ditekankan pada perbaikan struktur modal yang lebih menguntungkan.

\section{DAFTAR PUSTAKA}

Amah. 2016 Relationship Of Cash Flow Ratio and Financial Performance Of Listed Banks In Emerging Economies-Nigeria Example. Journal. Vol 4. Pp 89-97University Of Agricultur

Budiawan. 2009. Analisis Prestasi Keuangan Perusahaan Dilihat dari Rentabilitas, Likuiditas, dan Solvabilitas. Skripsi . Universitas Muhammadiyah Surakarta

Bursa Efek Indonesia. www.idx.co.id Di akses, 16 April 2018

Drs. Jumingan, (2011). Analisis Laporan Keuangan, Penerbit : PT. Bumi Aksara, Jakarta.

Drs. Darsono \& Ashari (2012). Pedoman Praktis Memahami Laporan Keuangan. Penerbit : ANDI Yogyakarta.

Dwi Prastowo 2015. Analisis Laporan Keuangan. Edisi Ketiga

Fedrik, Natan 2010. Analisis laporan keuangan tujuan menilai kinerja keuangan pada PT. Atra International, Tbk Periode 2007-2009. Akurat Jurnal Ilmiah Akuntansi. No.3 Tahun ke-1 September-Desember 2010. Fakultas Ekonomi Universitas Kristen Maranatha. Diakses 4 Juli 2018.

Hendry, Andres Maith. 2013. Analiss Laporan Keuangan Dalam Mengukur Kinerja Keuangan Pada PT. Hanjaya Mandala Sampoerna Tbk. Jurnal. Vol 1 No 3 Hal 619628. Universitas Sam Ratulangi Manado

Horngren, Harrison, Bamber, (2010). Akuntansi, Jilid 1, Edisi keenam, Penerbit : Indeks.

Ikatan Akuntansi Indonesia, 2009, standar akuntansi keuangan, PSAK No. 1 : Penyajian Laporan Keuangan. Jakarta : Salemba Empat

Ikatan Akuntan Indonesia, (2010). Standar Akuntansi Keuangan, Rineka Cipta, Jakarta.

John J. Wild, K. R. Subramanyam, Robert F. Halsey, (2012). Analisis Laporan Keungan, Salemba Empat.

Jumingan. 2016 Analisis Laporan Keuangan

K.R. Subramanyam 2017. Analisis Laporan Keuangan (Financial Statement Analysis). Edisi 11. Buku 1

Kasmir, (2012). Analisis Laporan Keuangan, Penerbit : PT. Raja Grafindo Persada, Jakarta.

Mamduh M. Hanafi 2016. Analisis Laporan Keuangan. Edisi Kelima

Marsel, Pongoh. 2013. Analisis Laporan Keuangan Untuk Menilai Kinerja Keuangan PT. Bumi Resources Tbk. Jurnal. Vol 1 No 3 Hal 669-679. Universitas Sam Ratulangi Manado

Munawir, S. 2012. Analisis Informasi Keuangan, Liberty, Yogyakarta 
Nengtyas, Dwiatmanto, dan Zahro. 2016. Teori Analisis Rasio Keuangan untuk Menilai Kinerja Keuangan Perusahaan (Studi pada PT Aneka Tambang (Persero) Tbk yang Terdaftar di Bursa Efek Indonesia Periode 2012

Nurhadi, D. 2010.Analisis yang digunakan Rasio Keuangan untuk Menilai Kinerja Keuangan pada Perusahaan Air Mineral yang go Public di Bursa efek Indonesia. Skripsi. Program Sarjana STIESIA. Surabaya.

Prinathara, I. B. T, (2010). Sistem Akuntansi Jasa Konstruksi Dilengkapi Ketentuan Perpajakan Cetakan Pertama, Penerbit : Graha Ilmu Yogyakarta.

Profil Perusahaan www.semenindonesia.com_di akses 14 Mei 2018

Praytino, Ryanto Hadi. 2010. Pedoman Analisa Laporan Keuangan Dalam Mengorek Kinerja Keuangan Perusahaan: Studi Kasus pada PT. X Jurnal Manajemen UNNUR Bandung. Vol 2 No 1. Universitas Nurtanio Bandung. Hal 9.

Soedjono. 2012. Analisis Laporan Keuangan Untuk Menilai Kinerja Keuangan Pada PG. Tjoekir Jombang. Jurnal. Vol 1 No 2. Universitas Widyagama Malang.

Sofyan Syafri Harahap, (2010). Analisis Kritis Atas Laporan Keuangan, Jakarta: PT. Raja Grafindo Persada.

Slamet Sugiri Sodikin, Bogat Agus Riyono, (2010).Akuntansi Pengantar 1, Edisi kedelapan, Penerbit : UPP STIM YKPN.

Setiawan, Irwan Amdani. 2013.Analisis RasioKeuangan untuk Mengukur Kinerja Keuangan PT Indocement Tunggal Prakarsa Tbk Sebelum dan Sesudah Akuisisi Periode 2007

Soemarso, (2013). Akuntansi Suatu Pengantar, Penerbit : Salemba Empat, Jakarta.

Sulayman, H Atieh. 2014. Liquidity Analisis Using Cash Flow Ratios as Compared toTradisional Ratio in the Pharmaceutical Sector in Jordan. The World Islamic Science \& Education University

Van Horne, James C, John M. Wachowics Jr, (2012). Prinsip-prinsip Manajemen Keuangan, Penerbit : Salemba Empat, Jakarta.

www.indocementtunggalperkasa.com_di akses 14 Mei 2018

www.holcimindonesia.com di akses 14 Mei 2018

Yogyakarta.Noor, Juliansyah. 2014. Metode penelitian. Kencana Jakarta 